\title{
ENVIRONMENTAL DISCOURSES AND THE QUESTION OF CREATIVE ENVIRONMENT IN A CITY
}

\author{
Tomas KAČERAUSKAS \\ Department of Philosophy and Communication, Vilnius Gediminas Technichal University, \\ Sauletekio al. 11, LT-10223 Vilnius, Lithuania
}

Submitted 10 Mar. 2015; accepted 08 Jan. 2016

\begin{abstract}
The paper deals with the different environmental discourses and the question whether the city is a creative environment. The theses have been developed as follows: 1) there are different environmental discourses including technological, sociological, ecological, religious, philosophical (ethical), urban, and discourse of creativity; 2 ) a novelty of a discourse follows from the interdisciplinary character, i.e. from a combination of the discourses; 3 ) a city both attracts and turns away the creative workers: here there are many occasions of creative activities and spreading of creation, however at the same time there is an anti-ecological environment that also uniforms creation; 4) although cosmopolitanism and globalism are intimately connected, they could be evaluated as two contrary principles: the first one is to be connected with the principle of difference, the latter - with the principle of unification; 5) although there are many debates concerning such social formation as the creative class, it is the main element and engine of a creative society.
\end{abstract}

Keywords: urban environment, social environment, creative city, creative class, environmental discourses, globalism.

\section{Introduction}

According to Florida (2012), it is a characteristic of the cosmopolitan city to show tolerance to strangers and intolerance to uniformity. First of all, the scholars face the question of what a cosmopolitan city is and why it is attractive or unattractive to creative workers. The term „,osmopolitan" consists of two Greek words kosmos and polis. The former refers to the ornament that an ancient Greek saw by looking at the sky and stars; the ornate universe is inseparable from astonishing order, incredible harmony and striking beauty ${ }^{1}$. Kosmos refers to surprising with an unapproachable whole of order, harmony and beauty. Plato (1992) appeals to it by creating a polis, a self-sufficient city-state that is just as well as ensuring the harmony of different creative individuals. Kosmos is a phenomenon that enforces the bracketing of creative aspirations in a polis for a new emerged whole. In this sense, it could be treated as an ecological principle that appeals to our natural and cultural limits.

\footnotetext{
1 Similarly, the starry sky astonished I. Kant (2003), who compared it with the moral law inside us.
}

Nevertheless, this term has experienced an inversion. By speaking about cosmopolitan city, the scholars have in mind certain variety of individuals and communities, certain cultural globalism and certain "liberations" from the national "prejudices". As a result, it presupposes a kind of elimination of certain traditions, of certain place, of certain localities and an orientation towards global language, culture and order. Herewith it is possible to talk about the inversions of connotations between kosmos and polis. In general, the terms and concepts develop regarding the cultural changes.

After the terms kosmos and polis have been wrested from the cultural and religious whole of antiquity, there are their new installations which have not fully "forgotten" the old connotations. This partial amnesia allows for the "liberating" of ancient terms and concepts for a new hermeneutic whole but it also pushes the culture to contradictions that should develop consequently.

The environmental discourses are as follows: technological, sociological, ecological, religious, philosophical (ethical), discourse of creativity, urban discourse. The methods and models used by the technological

Corresponding author: Tomas Kačerauskas

E-mail: tomas.kacerauskas@vgtu.lt 
environmental discourse comes partly from other discourses. Philosophical environmental discourse provides both the environmental ideas from the history of human thinking and a removed perspective including a critical approach.

The discourse of a creative city has been developed by Florida (2005, 2012), Landry (2000), in Lithuania by Samalavičius (2009), Butkus (2011), Lavrinec (2014a; 2014b), Bajarkevičius (2014), Čiupailaitè (2014), and Urbonaitè-Barkauskienè (2014). Creativity studies have been developed by Juzefovič (2013, 2015), Barevičiūtè (2014), Černevičiūtè, Strazdas (2014a, 2014b), Aglinskas (2014), Dūdènas (2014), Mitkus (2013), Štuopytė (2013), Valivonytè (2013), and Jonkus (2015). The problems of environment, including creative environment and creative city, have been analysed by Audretsch, Belitski (2013), Baltrènas et al. (2014), Baltrènas et al. (2015), Cetindamar, Gunsel (2012), Markert et al. (2012), Scott (2010), Tyrvainen et al. (2014), Vasarevičius et al. (2013), Juškevičius, Burinskienè (2007), Zaleckis (2011), and others.

\section{Technological environmental discourse comparing with other studies of environment}

The term "environment" has been used in many discourses including technological, sociological, philosophical, ecological, religious, philosophical (ethical), urban ones, as well discourse of creativity (see Fig. 1).

As result, there are different combinations of environmental discourses. Technological discourse of environment deals with sociological order and data, ecological subject, ethics of technologies, as well urban subject. Although the innovations play very important role in development of the technology, creativity in technological discourse should be related namely with interdisciplinary aspect, i.e. with combination with other discourses.

The Table 1 shows the possible combinations of environmental discourses and certain branches of sciences, as well culture (religion). The mark "+" shows a possible combination, the mark "-" - impossible combination, and the mark "'” - tautological combination. For example, it is possible to discuss religious implications to environmental approach (comp. Guth et al. 1995). Usually, the scientific approach presupposes the theses that could be "falsified" using a term of Popper (1983).

On the one hand, the scholars can search for environmental ideas in the history of philosophy (Attfield 1991). On the other hand, philosophy helps to reflect the environmental problems in social context from broader perspective and to test the very way of thinking (Janssens 2004) including religious connotations (Guth et al. 1995). The grounding of a new interdisciplinary environmental discourse is already philosophy because of appealing to different knowledge base. Beside this, many environmental discourses including technological one considers the ethical issues (Oughton, Strand 2002; Oughton 2003). Finally, one or another philosophy being a core of worldview does influence the environmental decisions (see Fig. 2). In the next chapters, the philosophical approach have been used by analysing city as creative environment.

According to Patavalis, Aravossis (2002), technological environmental approach appeals to the methods and

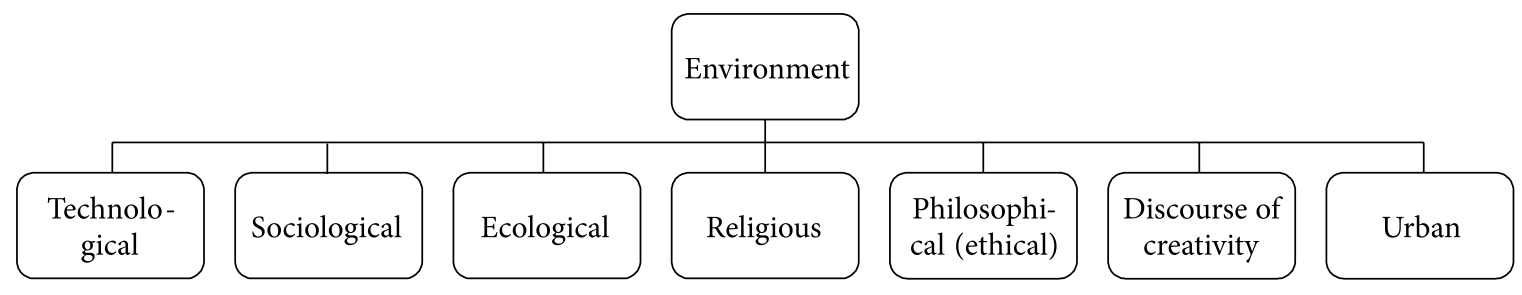

Fig. 1. Environmental discourses

Table 1. Combinations of environmental discourses

\begin{tabular}{|c|c|c|c|c|c|c|c|}
\hline & Technological & Sociological & Ecological & Religious & $\begin{array}{c}\text { Philosophical } \\
\text { (ethical) }\end{array}$ & $\begin{array}{l}\text { Creativity } \\
\text { discourse }\end{array}$ & $\begin{array}{c}\text { Urban } \\
\text { discourse }\end{array}$ \\
\hline Technology & ' & + & + & + & + & + & + \\
\hline Sociology & + & ' & + & + & + & + & + \\
\hline Ecology & + & + & , & + & + & + & + \\
\hline Religion & - & - & + & ' & + & + & - \\
\hline Philosophy (ethics) & + & + & + & + & ' & + & + \\
\hline Creativity studies & + & + & + & + & + & ' & + \\
\hline Urban studies & + & + & + & - & + & + & , \\
\hline
\end{tabular}


Table 2. Methods and models used in technological environmental discourse ${ }^{2}$

\begin{tabular}{|c|c|c|}
\hline Methods and models & Applied area & Authors and references \\
\hline \multirow[t]{3}{*}{ PROMETHEE and GALA methods } & nuclear waste management & Briggs et al. (1990) \\
\hline & oil and gas pipeline planning & Tavana et al. (2013) \\
\hline & $\begin{array}{l}\text { choice of systems for drying seeds and powder } \\
\text { materials }\end{array}$ & Prvulovic et al. (2011) \\
\hline \multirow[t]{4}{*}{ Multi-criteria model } & $\begin{array}{l}\text { selection of a technology for the disposal of } \\
\text { plutonium }\end{array}$ & Dyer et al. (1998) \\
\hline & post-earthquake sustainable reconstruction & Opricovic, Tzeng (2002) \\
\hline & measurement of sustainable performance & Ding 2005 \\
\hline & territory planning & Ustinovichius et al. (2011) \\
\hline \multirow[t]{3}{*}{ Regional planning model } & planning of an urban solid waste & Caruso et al. (1993) \\
\hline & urban planning & Juškevičius, Burinskienè (2007) \\
\hline & development of creative economy & Comunian et al. (2014) \\
\hline \multirow[t]{3}{*}{ Decision support system } & $\begin{array}{l}\text { effective planning and management of household } \\
\text { recyclable solid waste }\end{array}$ & Benson, Page (1998) \\
\hline & urban planning & Mitraka et al. (2014) \\
\hline & marine environmental & Baziuke et al. (2014) \\
\hline \multirow[t]{2}{*}{ ELECTRE III method } & solid waste management system & Hokkanen, Salminen (1997) \\
\hline & the oil and gas industry analysis & De Carvalho Infante et al. (2013) \\
\hline Heuristic method & planning of household waste disposal & Skordilis (1989) \\
\hline $\begin{array}{l}\text { Cumulative Energy Extraction from } \\
\text { the Natural Environment (CEENE) } \\
\text { method }\end{array}$ & $\begin{array}{l}\text { analysing of the environmental impact of marine } \\
\text { areal occupation }\end{array}$ & Taelman et al. (2014) \\
\hline $\begin{array}{l}\text { Methods for screening biofilm } \\
\text { formation in the laboratory }\end{array}$ & $\begin{array}{l}\text { Understanding of surface colonization in natural } \\
\text { environment }\end{array}$ & Fischer et al. (2014) \\
\hline Singularity expansion method (SEM) & Dielectric sphere in various environments & Mei (2014) \\
\hline Dezert-Smarandache theory & Multiple targets tracking in natural environment & Wang et al. (2013) \\
\hline $\begin{array}{l}\text { Geotechnical and hydrogeological } \\
\text { methods }\end{array}$ & Urban planning & Berhane, Walraevens (2013) \\
\hline Robotics methods & Environment and the objects therein & Toussaint et al. (2013) \\
\hline $\begin{array}{l}\text { Health promotion method for reducing } \\
\text { stress }\end{array}$ & Urban natural and built environments & Beil, Hanes (2013) \\
\hline $\begin{array}{l}\text { Polyacrylamide gel electrophoresis } \\
\text { (PAGE), field-flow fractionation (FFF), } \\
\text { and size exclusion chromatograph } \\
\text { (SEC) }\end{array}$ & Mass spectrometric measurements & Jimenez et al. (2011) \\
\hline Mono-window algorithm & Land surface temperature retrieval & Zhao et al. (2011) \\
\hline $\begin{array}{l}\text { Ion chromatography tandem mass } \\
\text { spectrometry (IC-ESI/MS/MS) method }\end{array}$ & $\begin{array}{l}\text { Quantification and conformation of chlorate in } \\
\text { environmental samples }\end{array}$ & Rao et al. (2010) \\
\hline Photorealistic ray tracing methods & Imperfect invisible spheres and invisibility cloaks & Danner (2010) \\
\hline $\begin{array}{l}\text { B3LYP and MP2 quantum chemical } \\
\text { methods }\end{array}$ & $\begin{array}{l}\text { Analysis of the tautomerism of the four most } \\
\text { stable conformers of the antiviral analogue } \mathrm{D} 4 \mathrm{~T} \\
\text { and natural thymidine nucleosides }\end{array}$ & Alcolea, Iza (2010) \\
\hline $\begin{array}{l}\text { Method of Gibbs free-energy } \\
\text { minimization }\end{array}$ & Calculation of thermodynamic equilibria & Gaskova et al. (2009) \\
\hline $\begin{array}{l}\text { Molecular evolutionary genetics } \\
\text { analysis (MEGA), Maximum } \\
\text { composite likelihood (MCL) }\end{array}$ & $\begin{array}{l}\text { Analyse of sequence alignments to estimate } \\
\text { evolutionary distances }\end{array}$ & Tamura et al. (2007) \\
\hline Comparative protein modelling & Rational design of mutagenesis experiments & Guex, Peitsch (1997) \\
\hline
\end{tabular}

\footnotetext{
${ }^{2}$ Although Table 2 does not refer to creativity directly, it shows the diversity of environmental discourses.
} 
models as follows: 1) PROMETHEE and GALA; 2) multicriteria model; 3) regional planning model; 4) decision support system; 5) ELECTRE III method; 6) heuristic method. Additionally, it appeals to CEENE, SEM, robotics, adaptive K-means methods and other methods, models and theories (see Table 2).

At least one of these models (regional planning model) follows from the urban studies. Some of them (multicriteria model, decision support system, geotechnical and hydrogeological methods, health promotion method for reducing stress) have been successfully used in the urban planning.

The mentioned regional planning model has been used also in development of creative industries, i. e. in policy of creative industries. Since the next chapters deal with creative environment in a city, it is worth to be mentioned.

Environmental protection covers the different factors and agents (see Table 3). The technology is only one of them. Usually, the agents of world-view are the public figures including the writers, philosophers and artists. The agents of the other factors (social, technological, economical, and political) are not only the theorists, the influence of which on decision making ${ }^{3}$ is very limited.

Table 3. Factors and agents of environmental protection ${ }^{4}$

\begin{tabular}{ll}
\hline \multicolumn{1}{c}{ Factor } & \multicolumn{1}{c}{ Agents } \\
\hline Factor of world-view & Public figures \\
Social & Sociologists, communities members \\
Technological & Engineers, users of the technology \\
Economical & Economists, businessmen \\
Political & Political theorists, politicians, \\
\hline
\end{tabular}

The interactions of mentioned environmental dimensions have been showed in Figure 2. Beside the interactions, it is possible to speak also about the conflicts and clashes both between the different interests and the environmental agents. There is no one environmental approach both within the scientific communities and within the groups of a society.

\section{Urban and creative environment}

The cosmopolitan city is full of contradictions. First of all, the question of the difference between a cosmopolitan and a global city does arise. A city is attractive and creative usually by appealing to its territory, culture, locality, i. e. to certain tradition. Territory here is an area of creative specialization in a city, which has been nourished both by global need and local environment. If the roots

\footnotetext{
3 More about environmental decision making see Carraro, Siniscalco 1993; Frank et al. 2000; Petersen 2009; Janssens 2004.

4 Although Table 3 appeals to the protection of physical environment, it shows the social aspects of it.
}

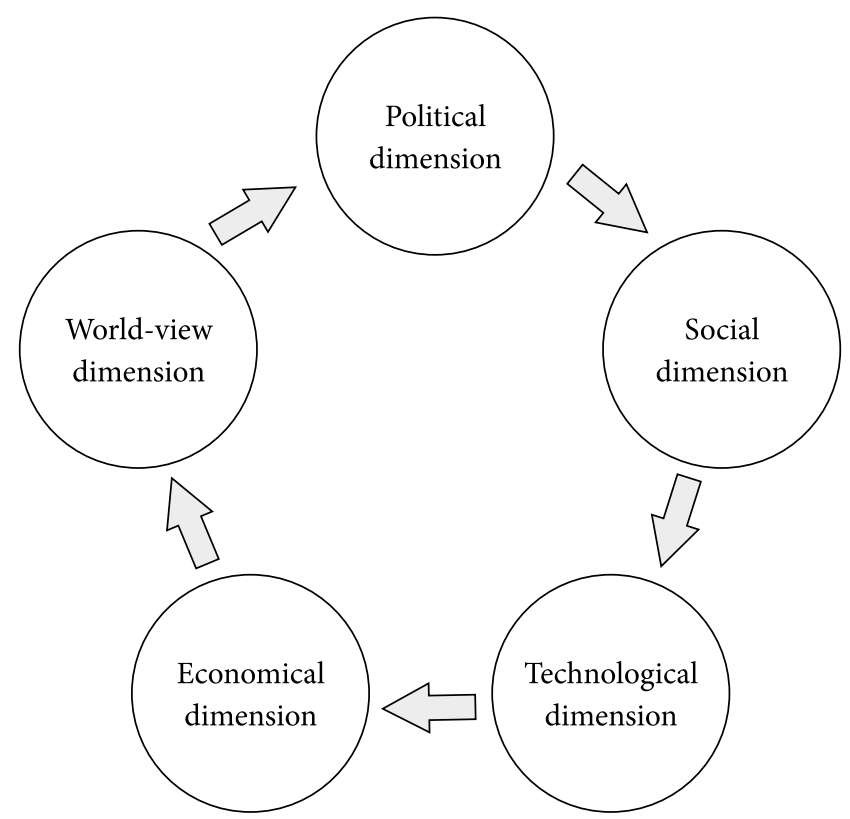

Fig. 2. Interactions of environmental attribution

of tradition have been cut and the local inequalities have been levelled, as a city orientates itself towards global tendencies, it loses identity and its culture becomes anaemic, finally not attractive. Nevertheless, a city is cosmopolitan because of the motley individuals represented by different languages, religions, robes, or skin colour.

On the other hand, a city is global because of certain features, buildings, signboards, fashions or life styles similar in different regions. The supermarkets, McDonalds, jeans, smart phones, life on credit, running through the streets and even the pursuit of ecology make the cities similar around the world despite their inimitable buildings and exceptional people. Zaleckis (2011) speaks about mentalscape, matterscape, and powerscape under the influence of globalization. Although cosmopolitanism and globalism are intimately connected, they could be evaluated as two contrary principles: the former is to be connected with acceptance of difference, the latter - with uniformity. The question arises to what extent either one attracts the creative workers and how much they represent a creative city.

In general, the bigger the city the more contradictory tendencies and conflicting situations it has. Tolerance to the strangers, including the creative workers with their different activity and life art, is not so much due to our morality, feeling of duty, principle of dialog, respect to strangeness or tolerance but rather from anonymity dictated by the enormous urban spaces. Some creative workers use this opportunity not only to spread his (her) works but also to live incognito.

If the ideas circulating in a city are attractive for the creative workers, although its noise (including noise of the 
media) and pollution are offensive, the scholars should speak about the optimal size of a city from the creative point of view. Remember Plato (1992), who spoke about a city of optimal size. It was about 20000 citizens, consequently, about 100000 people including the members (children and slaves) of citizens' families. A bigger city would not be harmonious because of inner contradictions such as national or religious, while a smaller one would not be self-sufficient, i.e. it could not satisfy emerging needs with its own resources. Similarly, the scholars could speak about a city of optimal size attractive for the creative workers. However, this optimal size depends on the state, culture, geography etc.

Florida (2012) assigns the creative class a modest role, i.e. to change details such as the nightlife of a city, insufficiently creative activities or non-dynamic approaches. The question why Florida underestimates the creative class presupposes three possible answers: 1) He is not as sceptical towards the development of the urban society as Horkheimer and Adorno (2002); 2) He is too optimistic towards creative class; 3 ) The perspective and the instruments of one science do not allow him to look at the city from the perspective of a creative society.

A city has a lot of cultural sources including both formal and informal: theatres, music-halls, philharmonics, cinemas, museums, universities, libraries, restaurants, churches. Furthermore, the spaces of a city could be used for different events, including the streets (for music festivals), squares (for installations and performances) or even the whole city (for firecrackers, light festivals). Florida appeals more to informal culture, i.e. street arts that are to be connected with music, art, cinema, recreation and nightlife. Beside this, tourism is inseparable from such forms of urban culture as the museums (Murphy, Schlaerth 2015). A city with its dynamic life is source of movement in general (Lingis 2015; Sakalauskaite 2015). Finally, informal culture also moves the formal one by giving it ideas. Society grows into a creative society through the influence of informal culture.

\section{Conclusions}

There are different sources and their combinations of environmental discourses. The environmental discourse is inseparable from technological, sociological, ecological, ethical, urban and other subjects. The scholars can search for environmental ideas in the history of philosophy that helps, in turn, to reflect the environmental problems in social context from broader perspective and to test the very way of thinking including religious connotations. Many environmental discourses including technological ones consider the ethical problems. On the other hand, one or another philosophy being a core of world-view does influence the environmental decisions.
A city could be treated as a creative environment. A city suggests many opportunities for the creative activities and creative workers. It is not clear why a city attracts the creative workers. The question of what the city's role is towards the creative workers stays open: does it attract or repulse them? A similar question also arises towards creative society: is the city the model of a creative society? Can the uniform tendencies of a city's mediated society be harmonized with the aspirations of a creative society? Probably, these things are inseparable from each other: creative ideas circulate in a mediated environment.

\section{References}

Aglinskas, V. 2014. Caught in the waiting game: community, creativity and everyday life in Šnipiškès, Santalka: Filosofija, Komunikacija 22(1): 77-86. http://dx.doi.org/10.3846/cpc.2014.07

Alcolea, P. M.; Iza, N. 2010. Tautomerism of the natural thymidine nucleoside and the antiviral analogue D4T. Structure and influence of an aqueous environment using MP2 and DFT methods, Physical Chemistry Chemical Physics 12(4): 881-893. http://dx.doi.org/10.1039/B915566J

Attfield, R. 1991. Has the history of philosophy ruined the environment?, Environmental Ethics 13(2): 127-137. http://dx.doi.org/10.5840/enviroethics199113222

Audretsch, D. B.; Belitski, M. 2013. The missing pillar: the creativity theory of knowledge spillover entrepreneurship, Small Business Economics 41(4): 819-836. http://dx.doi.org/10.1007/s11187-013-9508-6

Bajarkevičius, T. 2014. Garso meno praktikos miesto erdvèse [Sound art practices in city spaces], Santalka: Filosofija, Komunikacija 22(1): 69-76. http://dx.doi.org/10.3846/cpc.2014.06

Baltrènas, P.; Baltrėnaite, E.; Kačerauskas, T. 2015. Social environment of creativity, Filosofija Sociologija 26(1): 46-54.

Baltrènas, P.; Paliulis, D.; Vaiškūnaite, R. 2014. Experimental investigations and evaluation of pollutant emissions into ambient air by rolling stock engines, Polish Journal of Environmental Studies 23(3): 673-680.

Barevičiūtè, J. 2014. Pagrindiniai kūrybiškumo ir kūrybingumo aspektai šiuolaikiniuose humanitariniuose bei socialiniuose moksluose [The aspects of creativity and creativeness in contemporary humanities and social sciences], Filosofija Sociologija 25(1): 19-28.

Beil, K.; Hanes, D. 2013. The influence of urban natural and built environments on physiological and psychological measures of stress - a pilot study, International Journal of Environmental Research and Public Health, 10(4): 1250-1267. http://dx.doi.org/10.3390/ijerph10041250

Benson, J.; Page, W. 1998. A decision support system for the management of recycling schemes, Journal of Environmental Planning and Management 41: 445-462. http://dx.doi.org/10.1080/09640569811533

Berhane, G.; Walraevens, K. 2013. Geological and geotechnical constraints for urban planning and natural environment protection: A case study from Mekelle City, Northen Ethiopia, Environmental Earth Sciences 69(3): 783-798. http://dx.doi.org/10.1007/s12665-012-1963-x 
Baziuke, D.; Juscenko, N.; Siaulys, A. 2014. Switching to numerical scale in marine environmental decision support systems: Fuzzy logic approach, Ocean \& Coastal Management 101(SI): 35-41.

Briggs, T.; Kunsch, P. L.; Mareshall, B. 1990. Nuclear waste management: An application of the PROMETHEE methods, European Journal of Operational Research 44: 16-30. http://dx.doi.org/10.1016/0377-2217(90)90308-X

Butkus, T. S. 2011. Miestas kaip įvykis: urbanistinè kultūrinių funkcijų studija. Vilnius: Kitos knygos.

Carraro, C.; Siniscalco, D. 1993. Strategies for the international protection of the environment, Journal of Public Economics 52(3): 309-328.

http://dx.doi.org/10.1016/0047-2727(93)90037-T

Caruso, C., Colorni, A.; Parucini, M. 1993. The regional urban solid waste management system: a modeling approach, European Journal of Operational Research 70: 16-30. http://dx.doi.org/10.1016/0377-2217(93)90229-G

Černevičiūtè, J.; Strazdas, R. 2014a. Kūrybingumo sampratų raida: nuo genijaus ị kūrybines sistemas [Creativity understandings, evolution: from genius to creative systems], Santalka: Filosofija, Komunikacija 22(2): 113-125. http://dx.doi.org/10.3846/cpc.2014.10.001

Černevičiūtè, J.; Strazdas, R. 2014b. Meno inkubatorių vaidmuo, pletojant sistemų inovacijas [The arts incubators, influence on the development of system innovations]. Santalka: Filosofija, Komunikacija 22(2): 126-136. http://dx.doi.org/10.3846/cpc.2014.11

Cetindamar, D.; Gunsel, A. 2012. Measuring the creativity of a city: a proposal and an application, European Planning Studies 20(8): 1301-1318.

http://dx.doi.org/10.1080/09654313.2012.680583

Comunian, R.; Taylor, C.; Smith, D. N. 2014. The role of universities in the regional creative economies of the UK: Hidden protagonists and the challenge of knowledge transfer, European Planning Studies 22(12): 2456-2476. http://dx.doi.org/10.1080/09654313.2013.790589

Čiupailaitè, D. 2014. Architektų vaidmens ir statuso dilemos posocialistiniame mieste [The role and status dilemas of architects in postsocialist city], Santalka: Filosofija, Komunikacija 22(1): 15-37. http://dx.doi.org/10.3846/cpc.2014.03

Danner, A. J. 2010. Visualizing invisibility: Metamaterials-based optical devices in natural environments, Optics Express 18(4): 3332-3337. http://dx.doi.org/10.1364/OE.18.003332

Ding, G. K. C. 2005. Developing a multicriteria approach for the measurement of sustainable performance, Building Research and Information 33(1): 3-16. http://dx.doi.org/10.1080/0961321042000322618

Dyer, J.; Edmunds, T.; Butler, J.; Jia, J. 1998. A multiattribute utility analysis of alternatives for the disposition of surplus weapons-grade plutonium, Operations Research 46: 749-762. http://dx.doi.org/10.1287/opre.46.6.749

Dūdènas, J. 2014. Architektūrinio objekto perskaitymo sąlygos. Beepart atvejis [Conditions for reading the architectural object. The case of Beepart], Santalka: Filosofija, Komunikacija 22(1): 99-111.

De Carvalho Infante, C. E. D.; De Souza, A. M.; Bastos Do Valle, R. D. A. 2013. The oil \& gas industry analysis with the ELECTRE III method, Decision Making Systems in Business Administration 8: 123-132. http://dx.doi.org/10.1142/9789814452052_0012
Fischer, M.; Friedrichs, G.; Lachnit, T. 2014. Fluorescence-based quasicontinuous and in situ monitoring of biofilm formation dynamics in natural marine environments, Applied and Environmental Microbiology 80(12): 3721-3728. http://dx.doi.org/10.1128/AEM.00298-14

Florida, R. 2005. Cities and creative class. New York: Routledge.

Florida, R. 2012. The rise of creative class. New York: Basic Books.

Frank, D. J.; Hironaka, A.; Schofer, E. 2000. The nation-state and the natural environment over the twentieth century, American Sociological Review 65(1): 96-116. http://dx.doi.org/10.2307/2657291

Gaskova, O. L.; Bukaty, M. B.; Shironosova, G. P., et al. 2009. Absorption of bivalent heavy metals on calcite in naturaltechnogenic environments, Russian Geology and Geophysics 50(2): 87-95. http://dx.doi.org/10.1016/j.rgg.2008.06.018

Guex, N.; Peitsch, M. C. 1997. Swiss-model and the Swiss-Pdb viewer: an environment for comparative protein modeling, Electrophoresis 18(15): 2714-2723. http://dx.doi.org/10.1002/elps.1150181505

Guth, J. L.; Green, J. C.; Kellstedt, L. A., et al. 1995. Faith and the environment - religious beliefs and attitudes on environmental-policy, American Journal of Political Science 39(2): 364382. http://dx.doi.org/10.2307/2111617

Hokkanen, J.; Salminen, P. 1997. Choosing a solid waste management system using multicriteria decision analysis, European Journal of Operational Research 98: 19-36. http://dx.doi.org/10.1016/0377-2217(95)00325-8

Horkheimer, M.; Adorno, T. W. 2002. Dialectic of enlightment. Stanford: Stanford University Press.

Janssens, A. 2004. Environmental radiation protection: philosophy, monitoring and standards, Journal of Environmental Radioactivity 72(1-2): 65-73. http://dx.doi.org/10.1016/S0265-931X(03)00187-5

Jimenez, M. S.; Gomez, M. T.; Bolea, E., et al. 2011. An approach to the natural and engineered nanoparticles analysis in the environment by inductively coupled plasma mass spectrometry, International Journal of Mass Spectrometry 307(1-3): 99-104. http://dx.doi.org/10.1016/j.ijms.2011.03.015

Jonkus, D. 2015. Kūrybiškumo psichologija ir fenomenologija Vosyliaus Sezemano estetikoje [Psychology and phenomenology of creativity in Vasily Sesemann's aesthetics], Filosofija Sociologija 26(1): 55-63.

Juškevičius, P.; Burinskienė, M. 2007. Quality factors of the residential environment in urban planning, International Journal of Environment and Pollution 30(3-4): 471-484.

Juzefovič, A. 2013. Vaizdo vaidmuo siejant komunikacines strategijas filosofijoje ir sociologijoje [The role of the image in connecting commnicative strategies in philosophy and sociology], Filosofija Sociologija 24(3): 131-139.

Juzefovič, A. 2015. Creativity and aesthetic applied to ecological education, Creativity Studies 8(1): 12-24. http://dx.doi.org/10.3846/23450479.2014.1000410

Kant, I. 2003. Critique of practical reason. Cambridge: Cambridge university press.

Landry, C. 2000. The creative city: A toolkit for urban innovators. London: Earthscan Publications.

Lavrinec, J. 2014a. Community art initiatives as a form of participatory research: the case of street mosaic workshop, Creativity Studies 7(1): 52-65. http://dx.doi.org/10.3846/20297475.2014.933365 
Lavrinec, J. 2014b. Miesto studijos: tyrimo taktikos ir strategijos [Urban studines: research tactics and civic actions], Santalka: Filosofija, Komunikacija 22(1): 1-2.

Lingis, A. 2015. Building for movement, Creativity Studies 8(2): 103-114. http://dx.doi.org/10.3846/23450479.2015.1040475

Markert, B.; Wuenschmann, S.; Baltrènaitè, E. 2012. Innovative observation of the environment. Bioindicators and biomonitors: Definitions, strategies and applications, Journal of Environmental Engineering and Landscape Management 20(3): 221-239. http://dx.doi.org/10.3846/16486897.2011.633338

Mei, Z.; Lee, W.; Sarkar, T. K., et al. 2014. The natural resonant singularity expansion method (SEM) poles for a dielectric sphere in various environments, Microwave and Optical Technology Letters 56(3): 690-694. http://dx.doi.org/10.1002/mop.28169

Mitkus, T. 2013. Komiksai Lietuvoje: nepanaudotas kultūrinis ir edukacinis iqrankis [Lithuanian comics: Unused cultural and educations instrument], Santalka: Filosofija, Komunikacija 21(1): 21-34. http://dx.doi.org/10.3846/cpc.2013.03

Mitraka, Z.; Diamantakis, E.; Chrysoulakis, N., et al. 2014. Incorporating bio-physical sciences into a decision support tool for sustainable urban planning, Sustainability 6(11): 79828006. http://dx.doi.org/10.3390/su6117982

Murphy, J. W.; Schlaerth, C. A. 2015. Tourism at the museum and the life-world, Creativity Studies 8(2): 115-123. http://dx.doi.org/10.3846/23450479.2015.1033484

Opricovic, S; Tzeng, G. H. 2002. Multicriteria planning of postearthquake sustainable reconstruction, Computer-Aided Civil and Infrastructure Engineering 17(3): 211-220. http://dx.doi.org/10.1111/1467-8667.00269

Oughton, D. 2003. Protection of the environment from ionizing radiation: ethical issues, Journal of Environmental Radioactivity 66(1-2): 3-18. http://dx.doi.org/10.1016/S0265-931X(02)00113-3

Oughton, D.; Strand, P. 2003. Radiation protection in the 21(st) century: Ethical, philosophical and environmental issues, in Proceedings of The 3th Oslo Consensus Conference on Protection of the Environment, 129-136.

Patavalis, D; Aravossis, K. 2002. A realistic approach in evaluating programs and projects towards the protection and restoration of environment, in Proceedings of 6th International Conference on Protection and Restoration of the Environment Location, 1-5 July 2002, Skiathos Island, Greece, 1401-1409.

Petersen, T.; Klauer, B.; Manstetten, R. 1995. The environment as a challenge for governmental responsibility - the case of the European water framework directive, Ecological Economics 68(7): 2058-2065. http://dx.doi.org/10.1016/j.ecolecon.2009.01.008

Plato. 1992. The Republic. Indianapolis: Hackett publishing company.

Popper, K. R. 1983. Realism and the aim of science. London: Hutchinson.

Prvulovic, S.; Tolmac, D.; Radovanovic, L. 2011. Application of PROMETHEE-GAIA methodology in the choice of systems for drying paltry-seeds and powder materials, Strojniski Vestnik - Journal of Mechanical Engineering 57(10): 778-784.

Rao, B.; Hatzinger, P. B.; Bohlke, J. K., et al. 2010. Natural chlorate in the environment: application of a new IC-ESI/MS/MS method with a (ClO3-)-O-18 Internal Standard, Environmental Science \& Technology 44(22): 8429-8434.

http://dx.doi.org/10.1021/es1024228
Sakalauskaitè, E. 2015. Augmented reality as means of travel when picture changes the place, Creativity Studies 8(2): 95102. http://dx.doi.org/10.3846/23450479.2015.1052107

Samalavičius, A. 2009. Vartojantis ar kūrybingas miestas? [Consuming or creative city?], Logos 61: 170-178.

Scott, A. J. 2010. Cultural economy and the creative field of the city, Geografiska Annaler Series B-Human Geography 92(2): 115-130. http://dx.doi.org/10.1111/j.1468-0467.2010.00337.x

Skordilis A. 1989. Strategy evaluation in the planning of household waste disposal using the heuristic method, Technika Chronika, Scientific Journal of the Technical Chamber of Greece 9: 27-39.

Štuopytė, E. 2013. Unesco kūrybinių miestų tinklų poveikis miesto tapatumui [The influence of the UNESCO creative cities network on city's identity], Santalka: Filosofija, Komunikacija 21(2): 98-109. http://dx.doi.org/10.3846/cpc.2013.10

Tavana, M.; Behzadian, M.; Pirdashti, M., et al. 2013. A Promethee-GDSS for oil and gas pipeline planning in the Caspiansea basin, Energy Economics 36: 716-728.

http://dx.doi.org/10.1016/j.eneco.2012.11.023

Urbonaitė-Barkauskienè, V. 2014. Vilniaus graffiti žemèlapis kaip socialinès miesto kaitos indikatorius: Naujininkų rajono atvejis [The map of Vilnius graffiti as an indicator of social urban change: the case study of Naujininkai neighborhood], Santalka: Filosofija, Komunikacija 22(1): 53-68. http://dx.doi.org/10.3846/cpc.2014.05

Taelman, S. E.; De Meester, S.; Schaubroeck, T., et al. Accounting for the occupation of the marine environment as a natural resource in life cycle assessment: an energy based approach, Resources Conservation and Recycling 91: 1-10. http://dx.doi.org/10.1016/j.resconrec.2014.07.009

Tamura, K.; Dudley, J.; Nei, M., et al. 2007. MEGA4: Molecular evolutionary genetics analysis (MEGA) software version 4.0, Molecular Biology and Evolution 24(8): 1596-1599. http://dx.doi.org/10.1093/molbev/msm092

Tyrvainen, L.; Ojala, A.; Korpela, K., et al. 2014. The influence of urban green environments on stress relief measures: a field experiment, Journal of Environmental Psychology 38: 1-9. http://dx.doi.org/10.1016/j.jenvp.2013.12.005

Toussaint, M.; Lang, T.; Jetchev, N. 2013. Cognitive robotics challenges for our understanding of natural environments, Automatisierungs Technik 61(4): 259-267. http://dx.doi.org/10.1524/auto.2013.0027

Ustinovichius, L.; Barvidas, A.; Vishnevskaja, A., et al. 2011. Multicriteria verbal analysis of territory planning system's models from legislative perspective, Journal of Civil Engineering and Management 17(1): 16-26.

http://dx.doi.org/10.3846/13923730.2011.554173

Valivonyte, I. M. 2013. Plagijavimas reklamoje: kūrybinio mąstymo trūkumas ar perpildytos rinkos pasekmè? [Plagiarism in advertising: Lack of the creative thinking or result of saturated market?], Santalka: Filosofija, Komunikacija 21(2): 128-139. http://dx.doi.org/10.3846/cpc.2013.13

Vasarevičius, S.; Kadūnas, K.; Baltrènaitė, E. 2013. Comparison of requirements for environmental protection and a model for evaluating contaminated sites in Lithuania, Technological and Economic Development of Economy 19(1): 63-77. http://dx.doi.org/10.3846/20294913.2012.762954

Wang, Y.; Fang, Y.; Zhang, J., et al. 2013. Dezert-Smarandache theory for multiple targets tracking in natural environment, Iet Computer Vision 7(6): 456-466. http://dx.doi.org/10.1049/iet-cvi.2012.0193 
Zaleckis, K. 2011. Globalizacijos atspindžiai miesto kūne: keletas įžvalgų [Reflections of cultural globalization in cityscape: Few insights], Logos 66: 142-152.

Zhao, Sh.; Qin, Q.; Zhang, F., et al. 2011. Research on using a mono-window algorithm for land surface temperature retrieval from Chinese satellite for environment and natural disaster monitoring, (HJ-1B) Data, Spectroscopy and Spectral Analysis 31(6): 1552-1556.

Tomas KAČERAUSKAS. Professor, philosophy and communication. PhD from Vilnius University. Head of the Department of Philosophy and Communication at Vilnius Gediminas Technical University. Chair of Lithuanian Communication Society. Author of 5 books and more than 100 scientific articles in English, German, Russian, Polish, Slovakian, Ukrainian, and Lithuanian. Research interests: creativity studies, creative and culture industries, communication studies, and borderland studies. 